\title{
Formulasi Krim Lulur Scrab dari Ektrak Etanol Ubi Jalar Ungu (Ipomoea batatas (L.) Lam.) dan Serbuk Beras Putih (Oryza sativa L.)
}

\author{
Ika Maruya Kusuma ${ }^{1}$, Samha Aunillah ${ }^{1}$ dan Yayah Siti Djuhariah $^{1}$ \\ ${ }^{1}$ Institut Sains dan Teknologi Nasional, Jl. Moh Kahfi II Srengseng Sawah, Jakarta, 12640.
}

\author{
Reception date of the manuscript: 30 November 2020 \\ Acceptance date of the manuscript: 4 Desember 2021 \\ Publication date: 31 Desember 2021
}

\begin{abstract}
Purple sweet potato tubers (Ipomoea batatas (L.) Lam.) and white rice (Oryza sativa L.) are known to have antioxidant activity. This study aims to make a scrub cream formulation from ethanol extract of purple sweet potato and find out the most preferred formula. The purple sweet potato tubers were extracted with $70 \%$ ethanol solvent to form a thick extract. The thick extract then formulated into a scrub cream preparation which is divided into 3 formulas with variaous concentration of the extract, that is concentration of 2\% (FI), $4 \%$ (FII) and $6 \%$ (FIII), each formula is mixed with white rice powder as a scrub agent. Evaluation of scrub cream includes evaluation of physical quality (organoleptic test, homogeneity, type of cream, spreadability, viscosity, flow properties), $\mathrm{pH}$ test, accelerated stability test using the cycling test method and hedonic test (aroma, texture, color, sticky impression). The results of physical quality evaluation and stability test showed that the scrub cream obtained had good physical quality and stability. The hedonic test results show formula I is the most preferred formula.
\end{abstract}

Keywords-Body scrub cream, hedonic test, Ipomoea batatas (L.) Lam, Oryza sativa L, physical Stability

\begin{abstract}
Abstrak - Umbi ubi jalar ungu (Ipomoea batatas (L.) Lam.) dan beras putih (Oryza sativa L.) diketahui memiliki aktivitas antioksidan. Penelitian ini bertujuan untuk membuat sediaan krim lulur scrub dari ekstrak etanol ubi jalar ungu dan mengetahui formula yang paling disukai. Umbi ubi jalar ungu diekstraksi dengan pelarut etanol $70 \%$ hingga menjadi ekstrak kental. Ekstrak kental tersebut kemudian diformulasikan menjadi sediaan krim lulur scrub yang terbagi atas 3 formula dengan variasi konsentrasi ekstrak yaitu konsentrasi $2 \%$ (FI), $4 \%$ (FII) dan 6\% (FIII) yang masing masing formula ditambahkan serbuk beras putih sebagai bahan scrub. Evaluasi krim lulur scrub meliputi evaluasi mutu fisik (uji organoleptis, homogenitas, tipe krim, daya sebar, viskositas, sifat alir), uji pH, uji stabilitas dipercepat dengan metode cycling testdan uji hedonik (aroma, tekstur, warna, kesan lengket). Hasil evaluasi mutu fisik dan uji stabilitas menunjukkan krim lulur scrub yang diperoleh memiliki mutu dan stabilitas fisik yang baik. Hasil uji hedonik menunjukkan formula I merupakan formula yang paling disukai.
\end{abstract}

Kata Kunci-Ipomoea batatas (L.) Lam., Krim lulur scrub, Oryza sativa L, stabilitas fisik, uji hedonik.

\section{Pendahuluan}

Kulit merupakan organ yang menutupi seluruh tubuh manusia dan mempunyai fungsi untuk melindungi dari pengaruh luar. Pada umumnya, kulit mengalami regenerasi sel, sesuai dengan siklus normal pertumbuhan kulit ari dari lapisan tunas sampai menjadi lapisan tanduk terjadi dalam waktu 21 sampai 28 hari. Sel kulit mati yang menumpuk dari hasil regenarasi tersebut jika tidak dikikis akan menjadikan kulit tubuh terlihat kusam dan kasar, sehingga perlu adanya upaya perawatan pada kulit agar kembali halus dan bersih.

Perawatan kulit bisa dilakukan dari dalam dan dari luar. Perawatan kulit dari dalam yaitu merawat kulit dengan meng-

Penulis koresponden: Ika Maruya Kusuma, E-mail: imaruya@istn.ac.id konsumsi bahan makanan yang dapat menyehatkan kulit, sedangkan perawatan kulit dari luar yaitu perawatan yang dilakukan secara langsung pada kulit agar terlihat cantik, cerah, dan sehat. Perawatan kulit dari luar dapat dilakukan dengan berbagai cara seperti massage (pijat), mandi dan lulur. Lulur dapat mencerahkan dan membersihkan kulit dari sel-sel kulit mati, kotoran dan membuka pori-pori sehingga kulit dapat bernapas dan menjadi lebih cerah dan bersih.

Bentuk sediaan lulur antra lain lulur krim, lulur bubuk, dan lulur kocok/cair. Namun, bentuk sediaan krim dinilai lebih praktis dan mudah diaplikasikan. Tipe emulsi minyak dalam air memiliki keuntungan yaitu lebih mudah menyebar dipermukaan kulit, tidak lengket dan mudah dihilangkan dengan adanya pencucian serta lebih acceptable karena mudah diaplikasikan ke kulit serta meninggalkan rasa nyaman dibanding krim tipe air dalam minyak. 
TABEL 1: Formula KRIM LULUR $s c r u b$ )

\begin{tabular}{llllll}
\hline \multirow{2}{*}{ Bahan } & \multicolumn{4}{c}{ Jumlah (\%) } & \multirow{2}{*}{ Kegunaan } \\
& Blanko & FI & FII & FIII & \\
\hline Ekstrak ubi jalar ungu & - & 2 & 4 & 6 & Zat aktif \\
Serbuk Beras Putih & 15 & 15 & 15 & 15 & Scrub \\
Asam Stearat & 10 & 10 & 10 & 10 & Emulgator \\
Trietanolamin & 2 & 2 & 2 & 2 & Emulgator \\
Gliserin & 3.3 & 3.3 & 3.3 & 3.3 & Emolien \\
Polietilen Glikol & 2 & 2 & 2 & 2 & Humektan \\
Propil Paraben & 0,5 & 0,5 & 0,5 & 0,5 & Pengawet \\
Metil Paraben & 0,3 & 0,3 & 0,3 & 0,3 & Pengawet \\
Fragrance coklat & qs & qs & qs & qs & Pengaroma \\
Aquadest & Ad 100 & Ad 100 & Ad 100 & Ad 100 & Pembawa \\
\hline
\end{tabular}

Komponen lulur terdiri dari humektan, emolien, emulgator, bahan tambahan, scrub, dan juga bahan aktif seperti ekstrak tanaman. Tanaman yang bisa digunakan sebagai bahan aktif pada lulur umumnya mengandung antosianin yang dapat menghaluskan kulit seperti strawberry dan raspberry. Ubi jalar ungu (Ipomoea batatas (L.) Lam.) merupakan salah satu tanaman yang mengandung antosianin dan lebih stabil dalam penyimpanan (Ginting, 2011). Selain itu, pemanfaatan ubi jalar ungu sebagai bahan lulur belum diketahui oleh masyarakat karena penggunaannya hanya sebatas sebagai bahan makanan (Musdalipah., 2016). Selain itu penggunaan beras putih (Oryza sativa L.) dalam komponen lulur scrub belum banyak diketahui, padahal beras putih memiliki struktur kimia mirip dengan ceramide yang mampu memberi kontribusi pada proses regenerasi sel baru dan pertumbuhan pada kulit. Beras juga memberikan efek kelembaban dan air yang signifikan, selain itu juga membantu meningkatkan produksi kolagen yang meningkatkan elastisitas kulit dan membuat kulit cerah serta tampak lebih muda. Beras memiliki struktur yang kasar, sangat cocok digunakan sebagai scrub untuk tubuh yang mampu mengangkat sel-sel kulit mati.

Berdasarkan latar belakang diatas, peneliti tertarik untuk membuat sediaan krim lulur scrub dari ekstrak etanol ubi jalar ungu dengan konsentrasi sebesar 2\%, 4\% dan 6\% dengan penambahan serbuk beras putih sebesar $15 \%$, pengujian stabilitas fisik dan mengetahui formula yang paling disukai.

\section{BAHAN DAN METODE}

\section{Bahan dan Alat}

Bahan uji yang digunakan adalah ubi jalar ungu (Ipomoea batatas (L.) Lam.) yang diperoleh dari Balai Penelitian Tanaman Rempah dan Obat (BALITRO), Bogor, Jawa Barat. Kemudian diolah menjadi ekstrak etanol ubi jalar ungu, etanol $70 \%$ (Herbalux $\left.{ }^{\circledR}\right)$, amonia (Merck), kloroform (Merck), asam klorida (Merck), eter (Merck), asetat anhidrat (Merck), asam sulfat (Merck), beras putih (Rojolele $\left.{ }^{\circledR}\right)$, asam stearat (Shadhon bio-technologi), trietanolamin (Makincosmetics), polietilen glikol (Makincosmetics), metil paraben(Merck), propil paraben (Merck), gliserin (Brataco), dan fragrance coklat (Happy green $®)$.

Peralatan yang digunakan dalam penelitian ini yaitu neraca analitik (Kern), vacuum evaporator (EV400VAC), alatalat gelas (Pyrex), bunsen (phtc), viscometer (Brookfield LV$\mathrm{T})$, jangka sorong (Veanier), dan $\mathrm{pH}$ meter (Hanna), blender (Philips).

\section{Metode}

Bahan penelitian yang digunakan adalah ubi jalar ungu (Ipomoea batatas (L.) Lam.) yang telah dideterminasi di Herbarium Bogoriense Pusat Penelitian Biologi LIPI (Lembaga Ilmu Pengetahuan Indonesia), kemudian di ektraksi dengan pelarut etanol, dilakukan penapisan fitokimia, pemeriksan mutu bahan baku, pembuatan formula krim lulur scrub, evaluasi fisik, $\mathrm{pH}$, uji stabilitas sediaan dan uji hedonik krim lulur scrub ekstrak ubi jalar ungu.

\section{Persiapan Tanaman dan Pembuatan Ekstrak}

Ubi jalar ungu yang diambil dari perkebunan BALITRO sebanyak $10 \mathrm{~kg}$ disortasi basah untuk memisahkan kotoran atau benda asing yang menempel pada ubi, lalu dipotongpotong, dikeringkan dengan oven selama 48 jam. Selanjutnya ubi jalar yang sudah kering diserbuk. Serbuk ubi jalar ungu sebanyak 900 gram dimaserasi menggunakan etanol $70 \%$ sebanyak 9 L selama 24 jam dan sesekali diaduk pada 6 jam pertama kemudian didiamkan selama 18 jam. Filtrat kemudian ditampung, selanjutnya dipekatkan dengan vacuum rotary evaporatorhingga menjadi ekstrak kental. Ekstrak ubi jalar ungu yang dihasilkan selanjutnya dilakukan uji penapisan fitokimia. Uji penapisan fitokimia dilakukan pada ekstrak etanolubi jalar ungu yang terdiri dari uji alkaloid, tannin, flavonoid, saponin, steroid dan triterpenoid.

Pembuatan serbuk beras putih dengan cara mengambil sebanyak 500 gram beras putih dicuci bersih dengan air mengalir untuk menghilangkan kotoran yang melekat pada beras, setelah itu beras putih dikeringkan lalu dihaluskan, selanjutnya dilakukan pengayakan dengan menggunakan ayakan mesh 60.

\section{Pembuatan Krim Lulur Scrub}

Pemeriksaan mutu bahan baku dilakukan sebelum pembuatan sediaan. Pemeriksaan mutu bahan baku diantaranya pemeriksaan bahan tambahan seperti asam stearate, trietanolamin, gliserin, propilen glikol, propil paraben dan metil paraben dilakukan menurut yang tertera pada Certificate of Analysis (CoA) sesuai dengan persyaratan dalam Farmakope Indonesia Edisi V dan Handbook of Pharmaceutical Excipient 6th.

Krim Lulur scrub dibuat sebanyak 3 formula dengan blanko sebagai pembanding. Formula sediaan tertera pada Tabel 1. Semua bahan yang akan digunakan untuk membuat krim lulur scrub ekstrak etanol ubi jalar ungu ditimbang sesuai jumlahnya. Bahan-bahan fase air dan fase minyak dipisahkan 
yaitu fase air terdiri atas gliserin, metil paraben dan trietanolamin (TEA). Fase minyak terdiri atas asam stearat, propil paraben dan PEG. Fase minyak dan fase air dilebur dalam cawan porselin secara terpisah sampai semua bahan lebur. Dimasukkan fase minyak dan fase air dalam lumpang panas secara bersamaan kemudian digerus sampai homogen hingga membentuk krim lembut. Ekstrak etanol ubi jalar ungu dimasukkan kedalam campuran tersebut kemudian digerus sampai homogen, kemudian ditambahkan fragrance coklat dan serbuk beras putih lalu digerus kembali sampai homogen.

\section{Evaluasi Fisik Krim Lulur Scrub}

Sediaan krim dievaluasi meliputi parameter organoleptik terhadap bentuk, bau, warna, pemeriksaan homogenitas, tipe krim, daya sebar, viskositas dan $\mathrm{pH}$. Pemeriksaan organoleptis meliputi bentuk, warna dan bau yang diamati secara visual. Spesifikasi krim yang harus dipenuhi adalah memiliki konsistensi lembut, warna sediaan homogen, dan harum (Erawati et al., 2015).

Uji homogenitas dilakukan dengan meletakkan krim diantara dua kaca objek, kemudian diamati adanya butiran kasar atau tidak (Setiawati et al., 2015). Penentuan tipe krim dilakukan dengan teknik pewarnaan. Tiga tetes metilen blue diteteskan pada krim, kemudian diamati warna yang terbentuk. Jika emulsi berwarna biru seragam maka krim yang diuji berjenis m/a. Uji daya sebar, dengan menimbang 0,5 gram krim, kemudian diletakan diantara 2 kaca akrilik. Lempeng kaca bagian atas ditimbang terlebih dahulu kemudian diletakan di atas krim dan dibiarkan 1 menit lalu diukur diameter sebarnya. Kemudian ditambah beban dengan berat maksimum 150 gram dan diukur kembali diameter sebarnya (Swastika et al., 2013).

Penentuan viskositas bertujuan untuk mengetahui adanya perubahan kekentalan pada setiap formulasi krim. Penentuan viskositas dilakukan menggunakan viskometer Brookfield. Krim disiapkan dalam beaker glass $100 \mathrm{~mL}$. Kemudian memilih nomor spindel yang akan digunakan. Sifat alir diperoleh dengan membuat kurva antara tegangan geser dan laju geser. Pengukuran $\mathrm{pH}$ sediaan dilakukan menggunakan pH meter. Sebelum dilakukan pengukuran, $\mathrm{pH}$ meter, sebanyak 0,5 gram krim dilarutkan dalam $50 \mathrm{~mL}$ akuades. Sediaan krim yang telah dibuat diletakkan dalam suatu wadah lalu diukur $\mathrm{pH}$ nya.

\section{Uji Stabilitas Sediaan}

Stabilitas sediaan dipercepat ditentukan dengan metode cycling test. Sediaan krim disimpan pada suhu $4^{\circ} \mathrm{C}$ selama 24 jam lalu dipindahkan ke dalam oven yang bersuhu $40^{\circ} \pm$ $2^{\circ} \mathrm{C}$ selama 24 jam (satu siklus). Uji dilakukan sebanyak 6 siklus, kemudian dilakukan pengamatan organoleptis, pengujian homogenitas, pengujian nilai $\mathrm{pH}$, pengujian viskositas, pengujian sifat alir, pengujian daya sebar, dan pengujian pada sediaan krim sebelum dan sesudah cycling test.

\section{Uji Kesukaan (Hedonic Test)}

Uji kesukaan atau hedonic test dilakukan untuk mengetahui tingkat kesukaan panelis terhadap sediaan yang dihasilkan. Panelis merupakan anggota yang terlibat dalam penilaian organoleptik dari berbagai kesan subjektif dan analisa sifat-sifat sensorik suatu produk yang disajikan Ayustaningwarno et al. (2014).

Panelis pada penelitian ini berjumlah 30 orang dengan kri- teria: wanita berusia 17-23 tahun, berbadan sehat, tidak sedang menggunakan obat atau kosmetik lain, tidak ada riwayat penyakit yang berhubungan dengan alergi dan bersedia menjadi panelis. Pengujian dilakukan secara visual, setiap panelis diminta untuk mengaplikasikan sediaan pada kulit punggung tangan dan memberikan penilaian terhadap parameter aroma, tekstur, warna dan kesan lengket di kulit. Skala yang digunakan pada uji hedonik terhadap sediaan krim lulur scrub adalah skala 1-5 yang berturut-turut mewakili perasaan sangat suka (5), suka (4), cukup suka (3), kurang suka (2) dan tidak suka (1), selanjutnya dihitung persentase tingkat kesukaan.

\section{HASIL}

Hasil penapisan fitokimia ubi jalar ungu, memiliki metabolit sekunder alkaloid, tannin, flavonoid, saponin, steroid dan triterpenoid. Hasil pemeriksaan semua bahan baku krim melaui uji organoleptik sesuai dengan Certyficate of Analysis, Handbook of Pharmaceutical Exipients 6th, Farmakope Indonesia edisi V, sehingga dapat digunakan. Hasil evaluasi organoleptis krim lulur scrub pada hari ke 1-21, Formula 1, 2, dan 3 berbentuk setengah padat. Warna formula 1, 2, dan 3 secara berturut coklat muda cerah, coklat muda dan coklat muda gelap. Bau yang dihasilkan dari formula 1, 2, dan 3 yaitu bau coklat.

Hasil pengamatan homogenitas dari semua sediaan krim lulur scrub ekstrak ubi jalar ungu pada Blanko, Formula 1, 2 dan 3, hari ke 1-21 bersifat homogen. Penentuan tipe krim dari semua sediaan krim lulur scrub pada Blanko, Formula 1, 2 dan 3, hari ke 1-21 menunjukkan tipe minyak dalam air. Berdasarkan hasil pengujian daya sebar, rata-rata daya sebar sebelum dan sesudah cycling testdapat dilihat pada tabel 2 .

Hasil pengujian viskositas sediaan lulur krim ekstrak etanol ubi jalar ungu sebelum dan sesudah cycling testsecara berturut didapat pada Blanko 18.000-16.000 cPs, Formula 1 (F1) 20.000-19.000 cPs, Formula 2 (F2) 22.500-20.000 cPs dan Formula 3 (F3) 32.000-29.500 cPs. Hasil rheogram dapat dilihat pada gambar 1 .

Sediaan krim lulur scrub ekstrak etanol ubi jalar ungu memiliki nilai $\mathrm{pH}$ dengan interval yang masih memenuhi syarat $\mathrm{pH}$ sediaan yang berkisar $6,8-7,7$. Hasil pengukuran $\mathrm{pH}$ dapat dilihat pada gambar 2 .

Uji kesukaan atau hedonic test untuk mengetahui tingkat kesukaan panelis. Skala pengujian yang digunakan terhadap krim lulur scrub adalah skala 1-5 yang berturut-turut mewakili perasaan sangat suka (5), suka (4), cukup suka (3), kurang suka (2) dan tidak suka (1). Pengujian terhadap aroma, tekstur, warna dan rasa lengket terhadap formula 1, 2 dan 3 masing-masing formula hasil pengujian dapat dilihat pada gambar 3 .

\section{Pembahasan}

Berdasarkan hasil determinasi di Herbarium Bogoriense Badan Penelitian dan Pengembangan Botani, Pusat Penelitian dan Pengembangan Biologi, Lembaga Ilmu Pengetahuan Indonesia (LIPI), Jawa Barat, menunjukkan bahwa ubi jalar ungu yang digunakan dalam penelitian ini benar tanaman ubi jalar ungu (Ipomoea batatas (L.) Lam.) dengan famili Convolvulaceae. Ubi jalar ungu yang diperoleh dari perkebunan BALITRO sebanyak $10 \mathrm{~kg}$, kemudian dikeringkan, bobot simplisia kering ubi jalar ungu yang didapat sebanyak 3,5 kg. Simplisia kering tersebut dijadikan serbuk dan diayak 
Tabel 2: Hasil Pengujian Rata-Rata Daya Sebar Sebelum dan Sesudah Cycling Test

\begin{tabular}{ccccccccc}
\hline \multirow{2}{*}{ Beban } & \multicolumn{9}{c}{ Daya Sebar (mm) } & \multicolumn{3}{c}{ Sesudah } \\
\cline { 2 - 9 } & Blanko & F1 & F2 & F3 & Blanko & F1 & F2 & F3 \\
\hline 0 g & $46,30 \pm 0,02$ & $45,43 \pm 0,02$ & $44,69 \pm 0,01$ & $43,88 \pm 0,03$ & $48,65 \pm 0,01$ & $47,68 \pm 0,01$ & $46,24 \pm 0,01$ & $44,15 \pm 0,02$ \\
$150 \mathrm{~g}$ & $54,48 \pm 0,02$ & $53,46 \pm 0,01$ & $51,78 \pm 0,02$ & $50,41 \pm 0,03$ & $55,15 \pm 0,03$ & $54,43 \pm 0,01$ & $51,92 \pm 0,02$ & $50,53 \pm 0,03$ \\
\hline
\end{tabular}

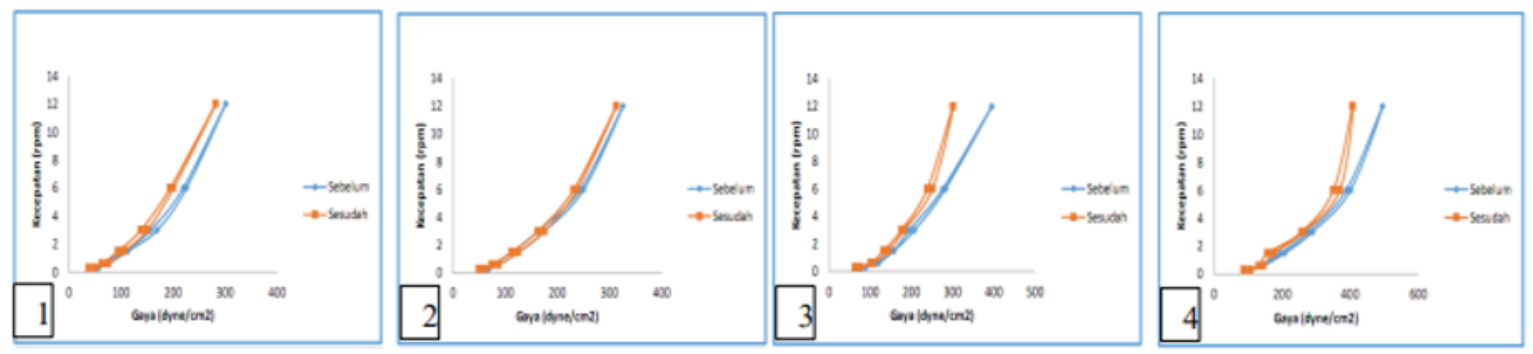

Gambar. 1: Hasil Viskositas cycling test; (1) Blanko, (2) Formula 1, (3) Formula 2, (4) Formula 3

dengan ayakan no. 60. Hasil rendemen serbuk ubi jalar ungu yang didapat sebanyak $35 \%$. Jumlah rendemen ekstrak kental yang diperoleh dari pelarut etanol sebesar 10,15\%. Hasil penapisan fitokimia, ubi jalar ungu memiliki kandungan metabolit sekunder alkaloid, tannin, flavonoid, saponin, steroid dan triterpenoid. Pelarut etanol 70\% dipilih karena merupakan pelarut yang bersifat polar yang baik untuk menarik flavonoid sebagai senyawa bahan alam yang berguna sebagai antioksidan (Lutpiatina et al., 2017)

Bahan baku untuk membuat sediaan krim lulur scrub terlebih dahulu diperiksa mutunya sebelum dilakukan formulasi melalui uji organoleptik. Adapun bahan-bahan yang diperiksa meliputi Asam stearat, Triethanolamine (TEA), Gliserin, Polietilen Glikol, Propil Paraben dan Metil Paraben. Hasil pemeriksaan semua bahan melaui uji organoleptik atau secara fisik yang meliputi bentuk, warna dan rasa dari masingmasing bahan baku sesuai dengan Certyficate of Analysis, Handbook of Pharmaceutical Exipients 6th, Farmakope Indonesia edisi V, berdasarkan hasil tersebut dapat disimpulkan bahwa semua bahan baku memenuhi syarat sehinga dapat digunakan.

Evaluasi organoleptis krim lulur scrub yang diuji pada hari ke 1-21, Formula 1 berbentuk setengah padat, warna coklat muda cerah, bau coklat. Formula 2 berbentuk setengah padat, warna coklat muda bau coklat dan Formula 3 berbentuk setengah padat, warna coklat mudagelap, bau coklat. Berdasarkan hasil pengamatan menunjukkan bahwa semua formula memiliki bentuk krim seperti yang dikehendaki pada perencanaan pembuatan yaitu berbentuk setengah padat. Sedangkan dari bau, setiap formula memiliki bau yang sama yaitu coklat, hal ini dikarenakan adanya penambahan fragrance berupa essence coklat pada proses formulasi untuk meningkatkan kenyamanan pada saat penggunaan.

Pengamatan uji homogenitas dari semua sediaan krim lulur scrub ekstrak ubi jalar ungu pada Blanko, Formula 1, Formula 2 dan Formula 3 hari ke 1-21 dikatakan homogenitas. Pada sediaan ditunjukkan dengan tidak terdapat partikelpartikel kasar pada sediaan dan warna sediaan merata (Musdalipah, 2016).

Penentuan tipe krim dari semua sediaan krim lulur scrub menggunakan metode pewarnaan dengan metil biru. Pada
Blanko, Formula 1, Formula 2 dan Formula 3 hari ke 1-21 menunjukkan, warna metil biru homogen atau tersebar merata di dalam semua formula, sehingga dapat dikatakan bahwa sediaan krim lulur scrub yang dibuat mempunyai tipe minyak dalam air (m/a). Tipe emulsi m/a memiliki keuntungan yaitu lebih mudah menyebar dipermukaan kulit, tidak lengket dan mudah dihilangkan dengan adanya pencucian serta lebih $a c$ ceptable karena mudah diaplikasikan ke kulit serta meninggalkan rasa nyaman dibanding krim tipe air dalam minyak $(\mathrm{a} / \mathrm{m})$.

Pengujian daya sebar dilakukan untuk mengetahui kemampuan penyebaran krim di permukaan kulit, semakin besar nilai diameter daya sebar maka akan semakin tinggi kecepatan menyebar dari setiap sediaan. Pengujian daya sebar bertujuan untuk melihat kemampuan menyebar krim diatas permukaan kulit saat digunakan. Krim yang baik memiliki daya sebar yang besar sehingga dapat digunakan pada permukaan kulit tanpa adanya penekanan yang berlebihan. Daya sebar 5-7 cm menunjukkan konsistensi semisolid yang sangat nyaman dalam penggunaan (Kindangen et al., 2018). Berdasarkan hasil pengujian yang dilakukan pada blanko dan ketiga formula krim lulur scrub, daya sebar krim lulur scrub mengalami peningkatan dari hari ke-1 sampai hari ke-21. Kemampuan menyebar krim lulur scrub ekstrak ubi jalar ungu terlihat baik, hal ini ditunjukkan dengan meningkatnya beban yang diberikan, daya sebar krim semakin meningkat. Daya sebar berkaitan dengan viskositas krim, apabila viskositas krim menurun dan tahanan cairan untuk mengalir semakin berkurang maka daya sebar krim semakin meningkat. Hal ini dibuktikan dengan menurunnya viskositas krim selama penyimpanan, daya sebar blanko dan ketiga formula cenderung meningkat.

Pada Tabel 2 menunjukkan data hasil pengamatan uji stabilitas kemampuan menyebar dari setiap sediaan. Berdasarkan pengujian yang dilakukan, diketahui daya sebar krim lulur scrub dari ekstrak etanol ubi jalar ungu mengalami sedikit kenaikan yang tidak signifikan $(\mathrm{p}>0.05)$ sesudah $c y$ cling testdan terjadi sedikit penurunan yang tidak signifikan ( $p>0.05$ ) nilai daya sebar, seiring meningkatnya jumlah ekstrak yang ditambahkan ke dalam sediaan. Hal ini terjadi karena semakin besar jumlah ekstrak yang dimasukkan menga- 


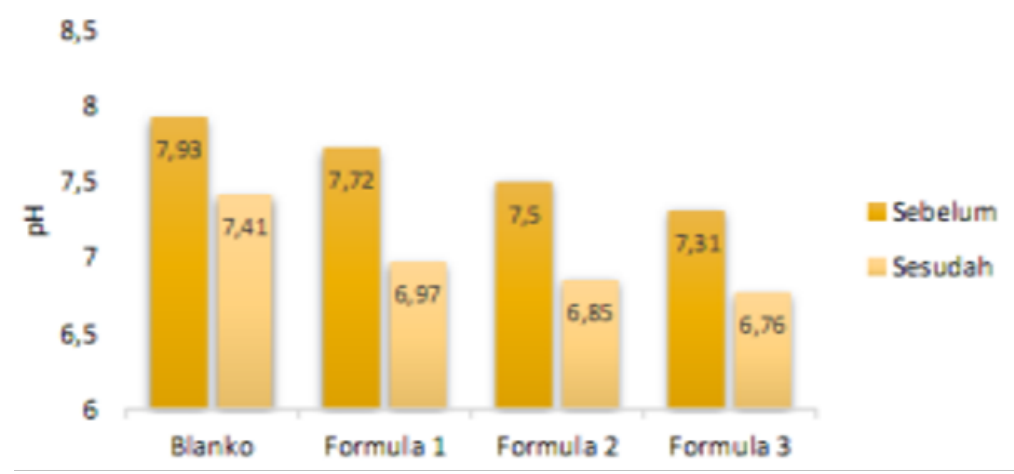

Gambar. 2: Rata-rata pH Krim Lulur scrub Sebelum dan Sesudah cycling test

1

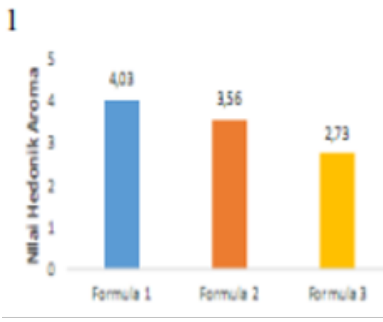

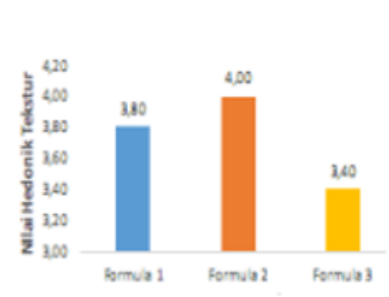

3

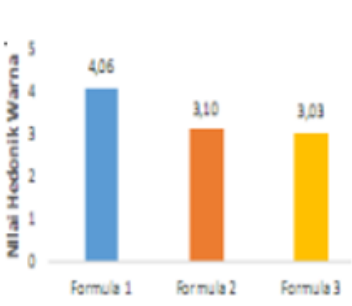

4

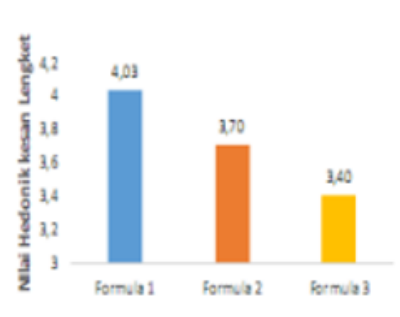

Gambar. 3: Hasil Uji Hedonik terhadap (1) Aroma, (2) tekstur, (3) Warna, dan (4) Rasa Lengket

kibatkan sediaan menjadi semakin kental sehingga kemampuan menyebar sediaan semakin rendah.

Respon viskositas krim lulur scrub berbanding terbalik dengan daya sebar, semakin rendah nilai viskositas maka semakin tinggi nilai daya sebar (Sayuti, 2015). Sediaan yang memiliki viskositas tinggi menghasilkan diameter penyebaran yang kecil sedangkan krim dengan dengan viskositas rendah (lebih encer) menghasilkan diameter yang lebih besar karena mudah mengalir (Kindangen et al., 2018).

Viskositas dan sifat aliran merupakan suatu pernyataan tahanan dari suatu cairan untuk mengalir. Semakin tinggi suatu viskositas maka semakin besar tahanannya. Respon viskositas krim berbanding terbalik dengan daya sebar, semakin rendah nilai viskositas maka semakin tinggi nilai daya sebar (Sayuti, 2015). Hasil pengujian viskositas sediaan lulur krim ekstrak etanol ubi jalar ungu sebelum dan sesudah cycling testdapat dilihat pada rheogram gambar 1 .

Hasil pengujian viskositas krim menunjukkan bahwa viskositas sediaan krim semakin meningkat seiring dengan bertambahnya konsentrasi ekstrak yang ditambahkan dalam sediaan. Viskositas sediaan krim mengalami penurunan setelah proses cycling test. Pada Blanko 18.000 menjadi $16.000 \mathrm{cPs}$, Formula 1 (F1) 20.000 menjadi 19.000 cPs, Formula 2 (F2) 22.500 menjadi 20.000 cPs dan Formula 3 (F3) 32.000 menjadi 29.500 cPs. Penurunan viskositas dapat disebabkan oleh kondisi lingkungan penyimpanan seperti temperatur, cahaya dan kelembaban udara. Kemasan yang kurang kedap dapat menyebabkan sediaan menyerap uap air dari luar, sehingga menambah volume air dalam krim (Ulfah et al., 2016).

Hasil rheogram (Gambar 1) meunjukkan semua formula lulur krim pada sebelum dan sesudah cycling testmemiliki sifat alir plastis tiksotropik. Disebut aliran plastis apabila kurva aliran tidak melalui titik $(0,0)$. Sedangkan sifat tiksotropik terlihat, kurva turun berada di sebelah kiri kurva naik. Berdasarkan grafik, terlihat bahwa pertama kurva menaik kemu- dian menurun. Hal ini menunjukkan bahwa krim tersebut memiliki nilai viskositas lebih rendah pada setiap harga kecepatan geser dari kurva yang menurun dibandingkan dengan pada kurva yang menaik. Hal tersebut lebih dikenal dengan sebutan tiksotropotik karena adanya pemecahan struktur yang tidak terbentuk kembali dengan segera jika tekanan tersebut dihilangkan atau dikurangi. Tiksotropotik merupakan suatu alir yang mempunyai konsistensi tinggi dalam wadah namun dapat dengan mudah dituang dari wadah dan juga mudah tersebar (Lutpiatina et al., 2017).

Berdasarkan hasil pengamatan sediaan krim lulur scrub ekstrak etanol ubi jalar ungu memiliki nilai $\mathrm{pH}$ dengan interval yang masih memenuhi syarat $\mathrm{pH}$ sediaan menurut SNI yang berkisar 4,5-8,0. Terdapat perbedaan nilai $\mathrm{pH}$ dari setiap formula, perbedaan konsentrasi ekstrak yang ditambahkan kedalam masing-masing formula mempengaruhi $\mathrm{pH}$ sediaan yang dibuat. Nilai $\mathrm{pH}$ semakin menurun seiring dengan peningkatan konsentrasi ekstrak etanol ubi jalar ungu yang digunakan pada setiap formula.

Uji kesukaan atau hedonic test dilakukan untuk mengetahui tingkat kesukaan panelis terhadap sediaan yang akan diuji. Skala yang digunakan pada uji hedonik terhadap produk krim lulur scrub adalah dari skala 1, yang berarti tidak suka sampai dengan skala 5, yang berarti sangat suka. Skala hedonik ini digunakan untuk menilai beberapa atribut yang dianggap penting dan menggambarkan karakteristik produk yang akan dipilih. Atribut kesukaan yang diamati meliputi atribut aroma, tekstur, warna dan kesan lengket dikulit, atribut-atribut tersebut dipilih untuk menggambarkan pengaruh perubahan konsentrasi ekstrak yang digunakan pada sediaan krim lulur scrub. Pada uji ini melibatkan 30 orang panelis, dimana setiap panelis diminta untuk menggosokkan sediaan pada kulit punggung tangan dan memberikan penilaian terhadap masing-masing sediaan. Kuesioner uji hedonik krim lulur scrub dari ekstrak ubi jalar ungu yang meliputi 
petunjuk pengisian, ketentuan dan petunjuk pengujian.

Aroma merupakan salah satu atribut sensori yang melekat pada suatu produk yang diamati dengan indera penciuman. Pada penelitian ini digunakan pengaroma coklat dengan konsentrasi yang sama pada setiap sediaan. Aroma yang dihasilkan dari ketiga formula memiliki tingkat aroma coklat yang berbeda-beda. Aroma formula 1, 2, 3 secara berturut aroma coklat kuat, coklat sedang dan coklat lemah.

Pada penilaian aroma yang dilakukan terhadap setiap formula krim lulur scrub diketahui bahwa formula 1 memiliki nilai kesukaan yang paling tinggi yaitu 4,03 sedangkan pada formula 2 dan 3 nilai kesukaan menurun berturut-turut sebesar 3,56 dan 2,75. Kecenderungan menurunnya ketertarikan panelis seiring dengan peningkatan konsentrasi ekstrak etanol ubi jalar ungu yang ditambahkan pada sediaan. Penurunan ketertarikan panelis tersebut juga dapat terjadi karena penambahan essence coklat pada setiap formula yang dimasukan sama rata, sehingga aroma coklat pada formula dengan konsentrasi ekstrak lebih banyak menjadi kurang tercium.

Penilaian pada atribut tekstur dilakukan untuk mengetahui tingkat ketertarikan panelis terhadap tekstur yang dimiliki oleh setiap sediaan. Formula 2 memiliki nilai kesukaan paling tinggi diantara formula lainnya dengan nilai sebesar 4,00; sedangkat nilai terendah dihasilkan oleh formula 3 dengan nilai sebesar 3,40. Hal ini dapat terjadi karena nilai viskositas/kekentalan dan jumlah scrub yang ditambahkan kedalam setiap sediaan, dari formula 1 sampai 3 memilki nilai viskositas yang berbeda-beda. Semakin besar jumlah ekstrak yang dimasukkan kedalam sediaan maka semakin besar nilai viskositasnya yang berarti sediaan menjadi semakin kental. Sedangkan untuk scrub dimasukkan sama rata pada setiap formula krim lulur scrub. Pada formula 3 dengan viskositas paling tinggi mengakibatkan partikel scrub pada sediaan menjadi lebih rapat dan membuat tekstur sediaan terasa lebih kasar. Sedangkan pada formula 1 dengan viskositas paling rendah mengakibatkan partikel scrub menjadi lebih renggang dan membuat tekstur sediaan terasa kurang kasar. Dari analisis tersebut dapat diketahui bahwa ketertarikan panelis menurun terhadap sediaan dengan tekstur yang terlalu kasar dan kurang kasar.

Warna merupakan salah satu atribut penampakan atau pengamatan visual yang melekat pada suatu produk. Warna produk krim lulur scrub yang dianalisis secara visual berkisar formula 1, 2, 3 dari coklat muda cerah sampai coklat muda gelap, variasi warna coklat muda yang dihasilkan disebabkan karena adanya perbedaan konsentrasi ekstrak yang ditambahkan pada setiap formula sediaan, semakin besar konsentrasi ekstrak yang ditambahkan ke dalam sediaan maka akan semakin gelap warna yang dihasilkan.

Pada penilaian warna yang dilakukan terhadap setiap formula krim lulur scrub diketahui bahwa formula 1 memiliki nilai kesukaan yang paling tinggi yaitu 4,06 sedangkan pada formula 2 dan 3 nilai kesukaan menurun berturut-turut sebesar 3,10 dan 3,03. Kecenderungan menurunnya ketertarikan panelis seiring dengan peningkatan konsentrasi ekstrak etanol ubi jalar ungu yang ditambahkan yang mempengaruhi warna dari sediaan yang dihasilkan. Hasil analisis ini mengindikasi adanya kecenderungan ketertarikan panelis untuk produk dengan warna yang lebih cerah. Pada formula 1 konsentrasi ekstrak yang ditambahkan lebih kecil yaitu $2 \%$ sehingga warna yang dihasilkan lebih cerah dibandingkan formula 2 dan 3 yang menyebabkan warna dari formula 1 lebih disukai oleh panelis. Perlu dilakukan perlakuan khusus dalam membuat sediaan krim lulur scrub dari ekstrak etanol ubi jalar ungu dan serbuk beras putih, agar tampilan krim lulur scrub menjadi lebih baik.

Penilaian kesan lengket dikulit dilakukan untuk mengetahui tingkat ketertarikan panelis terhadap sifat lengket dari setiap sediaan. Penilaian panelis untuk atribut kesan lengket dikulit cenderung menurun seiring meningkatnya jumlah konsentrasi ekstrak dari setiap formula. Formula 1 memiliki nilai kesukaan yang paling tinggi yaitu 4,03 sedangkan pada formula 2 dan 3 nilai kesukaan menurun berturut-turut sebesar 3,70 dan 3,40. Hal ini dapat disebabkan karena bahan aktif yang digunakan pada penelitian yaitu berupa ekstrak kental yang bersifat lengket, sehingga semakin besar konsentrasi ekstrak yang dimasukkan kedalamsediaan maka akan membuat sediaan tersebut menjadi semakin kental dan lengket.

\section{KESIMPULAN}

Hasil evaluasi mutu fisik dan uji stabilitas menunjukkan krim lulur scrub yang diperoleh memiliki mutu dan stabilitas fisik yang baik. Hasil uji hedonik menunjukkan formula I merupakan formula yang paling disukai.

\section{UCAPAN TERIMA KASIH}

Ucapan terimakasih disampaikan kepada LP2M Institut Sains dan Teknologi Nasional atas dukungan yang diberikan terhadap penelitian dan penulisan karya tulis ilmiah ini.

\section{Daftar Pustaka}

Ayustaningwarno, F., Rustanti, N., Afifah, D. N., \& Anjani, G. (2014). Teori dan Aplikasi Teknologi Pangan. November.

Erawati, E., Pratiwi, D., \& Zaky, M. (2015). Formulation Development and Evaluation of Physical Preparation Cream. $3(1)$.

Ginting, E. (2011). Potensi Ekstrak Ubi Jalar Ungu Sebagai Bahan Pewarna Alami Sirup. Pros. Semin. Nas. Has. Penelit. Tanam. Aneka Kacang dan Umbi, (pp. 755-767).

Kindangen, O. C., Yamlean, P. V. Y., \& Wewengkang, D. S. (2018). Formulasi Gel Antijerawat Ekstrak Etanol Daun Kemangi (Ocimum Basilicum L.) Dan Uji Aktivitasnya Terhadap Bakteri Staphylococcus Aureus Secara in Vitro. Pharmacon, 7(3), 283-293.

Lutpiatina, L., Amaliah, N. R., \& Dwiyanti, R. D. (2017). Daya Hambat Ekstrak Daun Kenikir ( Cosmos caudatus Kunth .) Terhadap Staphylococcus aureus. Meditory, 5(2), 83-91.

Musdalipah., d. (2016). Formulasi Body Scrub Sari Ubi Jalar Ungu (Ipomoea batatas L.) Varietas Ayamurasaki. War. Farm., 5(1), 88-98.

Sayuti, N. A. (2015). Formulasi dan Uji Stabilitas Fisik Sediaan Gel Ekstrak Daun Ketepeng Cina (Cassia alata L.). J. Kefarmasian Indones., 5(2), 74-82.

Setiawati, E., Nursal, F. K., \& Elfiyani, R. (2015). Pengaruh Peningkatan Konsentrasi Setil Alkohol Sebagai Pengental Terhadap Stabilitas Fisik Krim Tipe M/A Ekstrak 
Rimpang Jahe Gajah (Zingiber Officinale Rosecoe). (pp. $1-7)$.

Swastika, A. N., Muford, \& Purwanto (2013). ANTIOXIDANT ACTIVITY OF CREAM DOSAGE FORM OF TOMATO EXTRACT (Solanum lycopersicum L.). Antioxid. Act. CREAM Dos. FORM TOMATO Extr. (Solanum lycopersicum L.), 18(3), 132-140.

Ulfah, M., Fridayanti, A., \& Masruhim, M. A. (2016). Stabilitas Fisik dan Aktivitas Antioksidan Sediaan Gel Berbahan Aktif Ekstrak Etanol Daun Miana (Coleus antropurpureus Bent.). Pros. Semin. Nas. Tumbuh. Obat Indones. Ke-50, (April), 87-95. 